\title{
How to be a Theological Panpsychist, but not a Process theologian
}

\author{
Abstract \\ Follow these six easy steps and learn how a Christian theologian might \\ affirm panpsychism, without becoming a Process theologian. The Genetic \\ Argument for panpsychism is outlined in the first four steps: (1) affirm \\ mental realism, (2) deny psycho-physical reductionism, (3) affirm \\ fundamental monism, and (4) deny brute emergence. These four steps \\ result in a flexible version of panpsychism; the view that consciousness is \\ a fundamental and probably ubiquitous feature of the universe. During the \\ last century, panpsychism has been a part of the Process theologian's \\ arsenal. What then is the theologian, who disagrees with Process \\ metaphysics and rejects the Process doctrine of God, to do? To deny \\ Process theology this paper outlines two further steps: (5) maintain a \\ substance ontology, and most importantly, (6) affirm the doctrine of \\ creation ex nihilo. The result is a position I call 'theological \\ panpsychism'; a version of panpsychism compatible with traditional, \\ mainstream Christian theology. By taking these six steps, Christian \\ theologians can safely explore the potential theological benefits of \\ panpsychism, without fear that one is inadvertently advancing Process \\ theology.
}

Keywords: Panpsychism; Process theology; consciousness; evolution, creation ex nihilo, panexperientialism.

\section{Introduction}

The nature of consciousness continues to allude philosophers, theologians, and scientists alike. The problem can be stated in the following ways: How are we to hold the intuitiveness of dualism together with the elegance of monism? How can consciousness be both radically unique and part of an 
evolutionary account of biological development? If we are to make progress, then we must be willing to explore accounts of consciousness that may at first appear counterintuitive to our current ways of thinking. One commendable way to explore a new viewpoint is to try and defend it and so to examine the potential benefits 'from the inside'. In this way, this article takes up the mantle of defending panpsychism. Even if one wants to approach the question of consciousness with such an open-minded and flexible attitude, the desire for allies can tempt scholars to fall back into more well-known categories. For example, in exploring panpsychism one could simply join the camp of Process thinkers. But what of the theologian who has strong theological reasons not to affirm Process theology, and is still attracted to panpsychism? This article comes to such a theologian's aid as a how-to-guide for adopting theological panpsychism, without becoming a Process theologian.

Panpsychism is the claim that consciousness is a fundamental and (probably) ubiquitous feature of reality. Panpsychism is a very old and tenacious account of consciousness, which can be found in the writings of pre-Socratic Greece, Renaissance Italy, German Idealism, and contemporary speculations arising from quantum physics (Skrbina 2005). As we shall see, in addition to this historical pedigree, panpsychism holds some significant advantages over competing positions in philosophy of mind. Although panpsychism also contains its fair share of explanatory problems, it deserves serious and renewed attention from philosophers, theologians, and natural scientists alike who are interested in consciousness.

Before its most recent revival, Anglo-American panpsychism has been closely associated with the Process philosophy of Alfred North Whitehead. Since many of Whitehead's most prominent followers, such as Charles 
Hartshorne, John Cobb Jr., and David Ray Griffin were also Christian theologians, this has led to the false impression that for a theologian to adopt panpsychism entails affirming Process theology more widely. Panpsychism (or more precisely, panexperientialism) is only one string in the Process theologian's bow, which is accompanied by two more strings: an event ontology and a particular doctrine of God. These three strings are each necessary for a project to qualify as Process theology. However, these three aspects of Process theology do not implicate one another, and each can be maintained in isolation of the others. To this end, this paper disentangles theological panpsychism from Process thought, and shows how a theologian might affirm panpsychism as a theory of consciousness, without inheriting either an event ontology or the Process doctrine of God. The first half of this paper outlines how to be a panpsychist by following in the footsteps of a small group of contemporary analytic philosophers of mind. The result of these four steps is an argument for a basic, malleable form of philosophical panpsychism which is tied to no particular theological vision. The second half of this paper argues for two further steps, which prevent panpsychism from slipping into a version of Process philosophy or theology. Put simply, to affirm both Christian theism and panpsychism is not to adopt the Process doctrine of God. The conclusion presents the reader with an updated, but ancient Christian theory of the soul: theological panpsychism. In following this six-step guide, you too could become a theological panpsychist, but not a Process theologian.

\section{How to be a Panpsychist}

The first four steps in this how-to guide are inspired by three essays that have reshaped the field of analytic philosophy of mind; Thomas Nagel's “Panpsychism” (1979, 181-93), David J. Chalmers' "Towards a Scientific 
Basis for Consciousness" ([1994] 1997) and Galen Strawson's "Realistic Monism" (2006a). These landmark essays disentangled panpsychism from grand metaphysical schemes, such as Absolute Idealism, and inspired a new generation of philosophers to consider a panpsychist approach to the so-called 'hard problem of consciousness.' These authors defined panpsychism in a minimalistic way as the belief that "the basic physical constituents of the universe have mental properties." (Nagel 1979, 181) ${ }^{1}$ By presupposing that the universe has basic physical constituents Nagel placed panpsychism at an initial distance from idealism. Instead, this definition implies a dual-aspect, neutral monism, or as Strawson prefers a 'real materialism' (Strawson 2008, 2015). Since materialism has dominated twentieth century Anglo-American philosophy, it is unsurprising that Nagel's definition of panpsychism has been widely accepted, and that Strawson's panpsychist redefinition of materialism remains provocative.

Nagel's definition (or the one I gave above) ${ }^{2}$ carves out a unique space for panpsychism within the realm of ideas but leaves open for internal debate between panpsychists what the basic constituents of the universe are, or what exactly is meant by mental properties. Due to widespread misunderstanding it is important to emphasise that panpsychism does not mean that one posits a human-like cognitive process, rationality, or emotional kaleidoscope in all things. Panpsychism is not to be confused with the anthropomorphism of a mythic or paganistic view of druids in trees and rivers. Perhaps the only thing contemporary panpsychists agree

\footnotetext{
${ }^{1}$ Chalmers' definition is similar: "some fundamental physical entities are conscious; that is there is something it is like to be a quark or a photon or a member of some other fundamental physical type" (Chalmers 2015, 246-47).

${ }^{2}$ Panpsychism is the theory that consciousness is a fundamental and (probably) ubiquitous feature of reality. This allows for idealist and cosmosychist versions of panpsychism.
} 
on concerning the content of fundamental minds is that it is not like the content of human minds.

In this pioneering essay, Nagel suggests that each of these steps "is more plausible than its denial, though not perhaps more plausible than the denial of panpsychism.” (Nagel 1979, 181) However, what seems plausible or intuitive changes over time. This how-to guide then asks readers to allow this panpsychist construction to stand for a while, in order to let the dough of intuition slowly rise. For thirty years later, in his controversial book Mind and Cosmos, Nagel argued more positively that panpsychism or neutral monism is the only way to make sense of consciousness in light of evolutionary biology. Galen Strawson similarly testifies to the demystifying effect of time on panpsychism when he writes, "This sounded crazy to me for a long time, but I am quite used to it, now that I know that there is no alternative short of 'substance dualism'...” (2008, 71). Why do these esteemed philosophers find panpsychism so compelling? To answer this question, we need to follow their footsteps.

\section{a) Step 1: Affirm Mental Realism}

The first step towards theological panpsychism is to affirm the reality of mental experience, or consciousness more broadly. This should not be difficult. Afterall the ability to make such an affirmation is evidence for the facticity of the claim. Consider the following,

So far as I know, the existence of... states of consciousness... has never been doubted by any critic, however sceptical in other respects he may have been. That we have cognitations of some sort is the inconcussum [unknockable-out thing] in a world most 
of whose other facts have at some time tottered in the breath of philosophic doubt (James [1890] 1950, 185).

At the end of the $19^{\text {th }}$ century, William James could make the above statement with confidence; no philosopher had doubted the existence of consciousness or the ability for mental experience. This peculiar scepticism belongs to the twentieth century and, as Galen Strawson writes, "is surely the strangest thing that has ever happened in the world history of human thought" and "the deepest irrationality of the human mind" (Strawson 2008, 6). Regardless of our difficulty of explaining it, consciousness is an undeniable aspect of human existence. To think otherwise, is to disprove one's own argument. What is sometimes advertised as the denial of consciousness then, is in fact only its reduction.

\section{b) Step 2: Deny Psycho-Physical Reductionism}

To reduce the experiential to the entirely non-experiential (commonly called, physical) properties, their relations, and functioning is to suggest that consciousness is an illusion in some sense. Consciousness is something that can be explained in purely physical or material terms, like a magic trick that can be reduced to a distraction or a slight of hand.

This reduction of consciousness goes under many guises, the most common being 'physicalism', 'materialism' or even more broadly 'naturalism'. Positively stated, these views state that everything that exists, both in terms of substances and all properties, is material, physical, or natural. But what does it mean for something to be physical, material, or natural? These categories (and their supposed antonyms such as immaterial, spiritual, or supernatural) denote the means of investigation appropriate the object in question. Thus, the criteria for something being physical, material, or natural is that it can be investigated, in some way, by the physical, material or natural sciences (just as, the criteria for something 
being spiritual is that is can only be discovered or encountered through faith, grace, spiritual exercises or religious ritual). This should not be confined to what current physics defines as physical, but a hypothetical 'perfect' physics which has discovered everything there is to discover through a chain of explanatory inference from our current knowledge (Nagel 1979, 183; cf. Feigl 1958).

To affirm mental realism is not only to admit that thought and experience exist (as one must to avoid self-contradiction), but is it also to affirm that experience, awareness, or the general feeling of 'what it is like' to be a conscious subject is qualitatively different from the quantifiable measurements of speed, electromagnetic force, density or energy joules. That is, mental experience cannot be exhaustively explained, and thereby reduced to, physical behaviour or functions. Step 2 is really an extension of Step 1, but one that until recently a surprising number of contemporary philosophers refused to take. What has caused this recent change?

The qualitative difference that experience makes between the mental and the material is captured by Frank Jackson's famous thought experiment of Mary in a black and white room (Jackson 1983). Put simply, no matter how much scientific knowledge Mary has about colours, the refraction of light along wavelengths and the neurochemistry of how human's detect colours, Mary would not know what it is like to see red unless she stepped outside of her black and white room. There is something qualitatively different about this experiential knowledge (seeing the colour red) that cannot be reduced to even a complete scientific description of red.

Jackson's thought experiment takes an isolated case of one phenomenal experience (seeing red), but even before Mary steps outside the black and white room she is, presumably, a conscious subject. Thus, a more powerful thought experiment might include every aspect of a person's cognitive 
functioning. One famous example of this type of thought experiment comes from David J. Chalmers. Chalmers created the idea of a philosophical zombie, or p-zombie (cf. Kirk 2019). Unlike its apocalyptic namesake, a p-zombie is physically exactly identical to a normal human, except that it lacks any conscious experiences. These imagined creatures help philosophers clarify the role of the physical body in discussions of consciousness. Chalmers argues that p-zombies are at least conceivable (although perhaps not practically possible). If he is right about this then it suggests that there is something more to consciousness than physicality, functioning, and the structure or behaviour of the physical system.

Chalmers argued that physical abilities and behaviour may explain some cognitive functions that we closely associate with consciousness (so-called 'easy problems'), but we will never explain felt experience this way; physicality will never tell us why the 'lights are on' inside the human organism. This question of phenomenal consciousness or felt experience, Chalmers famously dubbed "the hard problem of consciousness" (1997).

These recent thought experiments all draw upon the same intuition first described by Gottfried Wilhelm von Leibniz, who along with William James, should be considered one of the founding fathers of modern panpsychism. Leibniz argued that even if scientists could perfectly observe the physical workings of the brain or body, as we can observe the pushing and pulling of levels in a mill, this would not get us any closer to understanding the nature of perception and experience (Leibniz 1899, 22728). To Leibniz, as to Jackson, Chalmers and panpsychists more widely, the mind is "inexplicable on mechanical grounds" (Leibniz 1899, 228). These thought experiments and others like them carve the world into two; the material world described by a completed scientific knowledge and the immaterial world of first-person experience, or what-it-is-like to exist as a 
conscious being. Those who hold to this division in the world are dualists of one sort or another. As Chalmers is quick to argue, "to embrace dualism is not necessarily to embrace mystery," or to imply that there is something transcendental or spiritual about consciousness; "it is just another natural phenomenon." $(1996,126,128)$ As is argued in step six, this deflation of the connection between consciousness and spirituality is, in fact, a great theological benefit. In keeping with the doctrine of creation ex nihilo, consciousness is just another created phenomenon.

\section{c) Step 3: Affirm Fundamental Monism}

Yet the dualist has a problem. The division of the world into material and immaterial substances cannot be sustained with absoluteness. Our knowledge of the material and experiential are completely interwoven: we cannot experience the material world apart from our conscious subjectivity; our material bodies condition every aspect of our experience; and it is the material world beyond one's own body of smells, sunsets, and sausages that fills our lives with experiential content. If these two aspects of reality, the material and the experiential, are so qualitatively different that we must carve reality into two completely different substances how is it that these two substances so thoroughly and entirely interact? This interaction is not an occasional bumping-up against one another, but a radical interdependence and continuous exchange. To live an embodied life is to experience material properties. To form personal relationships in communities (or as artistic expressions manifest most clearly) is for something of our experiential inner-life to be made partially (although not wholly) communicable into a public and material form.

The question of interaction, or rather of transference, between the material and the experiential is not yet so severe that it enjoins one to abandon the reality of the material or, even less so, the existence of mental experience. 
However, it does require a response. What kind of story might a dualist tell that could account for this interactive transference between matter and mental experience?

The panpsychist answers the dualistic interaction problem by maintaining a commitment to fundamental monism. For panpsychists human beings are wholly composed out of one type of stuff, which in principle can be shared with or replaced by anything else in the universe. The matter that currently composes me, the living organism referred to as 'I', was once probably part of a star, perhaps a rock, and maybe grass that was eaten by a cow whose milk was drunk by my mother. This recyclable stuff is all there is too me; this stuff is enough to make a living, conscious organism. Whilst Steps 1 and 2 give rise to dualism of one type or another, Step 3 rules out Cartesian substance dualism. That is, it rules out the view that there are two substances occasionally found together (as in human beings) but can also persist apart, as in rocks and angels, and identifies ' $\mathrm{I}$ ' only with the immaterial substance. By contrast, for panpsychists there is one fundamental level of reality, one type of stuff that all things, rocks and angels, organisms and orangutans, are made out of. If this is the case what we refer to as 'matter' must be pretty special - as capable of being described in both physical and mental terms. ${ }^{3}$

This is, in fact, not a radically novel insight. Many great minds of the past, such as John Locke, David Hume, Immanuel Kant, Bertrand Russell, Noam Chomsky and others, have pointed out that we know next to nothing about 'matter', and so cannot be certain that materiality excludes mental properties (Strawson 2008, 20, 39). For a panpsychist to say that the mind is material, then, is not to say that the mind can be reduced to the

\footnotetext{
${ }^{3}$ It is possible to be a substance dualist and affirm fundamental monism, if and only if one also affirms that this one type of stuff is always composed of both substances which cannot be separated.
} 
functional interaction of physical parts. Instead it is to say that even the most basic 'physical' things - properly understood - contain mental properties (Strawson 2008, 19-20, 46-47). As Strawson argues "Descartes' greatest mistake" was not dualism in general, but the assumption that we know enough about the nature of spatial-extension to place it in opposition to conscious experience (Strawson 2008, 46). The panpsychist's commitment to fundamental monism aims to unsettle our modern notions of matter, as well as our intuitions regarding the mind.

The panpsychist's commitment to a fundamental monism, that there is one fundamental level of reality which contains all the necessary ingredients for psychophysical life, keeps panpsychism within the stream of contemporary scientific thought. Panpsychists refuse to surrender consciousness to reductionism, and thereby claim to "take consciousness seriously" (Chalmers 1996, xii-xiii) - but it would be hasty and uncharitable to thus label panpsychism 'unscientific'. Panpsychists also claim to be "scientifically 'hard-nosed"," and to "take science seriously," because their theory lies within the search for a thoroughly scientific explanation of consciousness (Strawson 2015, 202; Chalmers 1996, xiixiii). Here, the definition of science is to explain complex and apparently mysterious aspects of reality in terms of "a few fundamental entities connected by fundamental laws" (Chalmers 1997, 20; cf. Nagel 2012, 42). Panpsychism posits that there are fundamental mental entities connected by psychophysical laws. Beyond following this idealised structure of scientific explanation, panpsychism also boasts successful traction with one of the most important discoveries of contemporary science; namely, Darwinian evolution.

The affirmation of fundamental monism (step 3) maintains the evolutionary premise of ontological continuity between all things in the biological 
world, and indeed beyond. The importance of this continuity for evolutionary thinking is seen even in early evolutionary thinkers such as Ernst Haeckel, William Kingdon Clifford, Morton Price, Sir Charles Scott Sherrington, Sir Julian Huxley and Pierre Teilhard de Chardin (Skrbina $2015,131-133,141-144,191-192)$. William James went so far as to claim that panpsychism "is an indispensable part of a thorough-going philosophy of evolution.” (James [1890] 1950, 149; cf. Skrbina 2015, 147-49). Nagel's recent Mind and Cosmos picks up this Jamesian line of thinking to argue that the undeniable existence of consciousness deems the entire materialist neo-Darwinian interpretation of evolution to be almost certainly false. Instead, to fully understand the evolution of mentality into the complex systems of thought that human minds are capable of we must rethink our conception of nature such that it includes mentality from the beginning. In Nagel's words, the most likely picture in light of evolutionary depicts "all the elements of the physical world [as] also mental.” $(2012,57)$

\section{Step 4: Deny Brute Emergence}

But wait, what about emergence theory? The emergence theory of consciousness can also claim Steps 1-3 and can do so without positing the counterintuitive claim that consciousness is in everything. Emergence theory has found a great ally in evolutionary biology, and in some theories the terms 'emergence' and 'evolution' have almost become synonyms (Graves 2008, 99; Clayton 2004, 85). As the emergence theologian Philip Clayton writes, "emergence is the theory that cosmic evolution repeatedly includes unpredictable, irreducible, and novel appearances." $(2004,39)$ The only form of emergence relevant to this paper is the claim that consciousness is an emergent property. This is the idea that unpredictable, irreducible, and novel mental properties emerge out of wholly non-mental or non-experiential matter. To be a panpsychist, one must reject this claim. 
A popular way to do this, following Nagel again, is to deny not only the emergence of consciousness but any ontological form of emergence. Nagel argues that emergence can only be true as an epistemological claim, meaning that "an observed feature of the system cannot be derived from the properties currently attributed to its constituents." $(1979,182)$ But this falls short of the stronger ontological claim that such properties do not exist within the constituent parts. Nagel argues that without a panpsychist base the ontological emergence of consciousness entails a Humean account of causation.

According to Scottish philosopher David Hume, causal necessity is an illusion and all we really observe are regularities or correlations between two events (one we label 'cause' the other event we label 'effect'). The non-necessary, but merely regular, relationship between a cause (like heat) and an effect (like boiling water) means that there is nothing about the heat that makes water boil, heat just regularly correlates to the effect of water boiling. This is the kind of non-causal explanation that the claim that mental properties emerges out of wholly non-mental things relies upon. On the emergentists account of consciousness, a mental event (like, the experience of pain) correlates to, but is not necessitated or caused by, a physical state of affairs (like, putting your hand in boiling water). According to emergence theory, the mental event of pain may depend or supervene upon the physical event, but it is not caused by the physical state of affairs (neurons firing in my brain as my hand is submerged into the boiling pan). There is nothing in the causal base that makes or necessitates that an emergent property appears, but it just regularly does so - emergence can in principle offer no explanation for why this occurs. In this sense of ruling out any hope of explanation, emergence is a brute relation. The emergentists story of consciousness relies upon a Humean account of causation. 
A Humean account of causation, and the abandonment of a causal explanation, is a steep price to pay; for by positing a non-causal correlation between phenomena our investigations are effectively brought to a halt. Whilst all theories have a brute element, the hope is that this will be at the earliest point in cosmic history or at the most basic level of reality; not in the day-to-day generation of organisms or their regular behaviour. ${ }^{4}$

When faced with apparent (epistemological) cases of emergence we do not have to accept Humean causation and postulate that new ontological properties can somehow emerge from constituents that have no properties of that kind. Instead, the unpredictability and novelty of apparently emergent properties "is a reason to conclude that either the system has further constituents of which we are not yet aware, or the constituents of which we are aware have further properties that we have not yet discovered." (Nagel 1979, 182) If there is a causal explanation for some mental events (e.g. that alcohol leads to uninhibited behaviour or drowsiness) then there must be intrinsic properties in matter that cause these mental events, and these intrinsic properties will not be purely physical properties (Nagel 1979, 187; cf. Strawson 2008, 74). For the emergence relation to work, mental properties must be built in at the bottom; found at the fundamental level. The emergence of consciousness requires a panpsychist concept of matter.

If one follows this path developed by a few contemporary analytic philosophers of mind, then one is justly called a panpsychist. The argument contained in Steps 1-4 can be summarised thus: since it is certain that purely material organisms can be conscious, and highly probable that consciousness can neither be reduced to nor emerge out of

\footnotetext{
${ }^{4}$ Nagel suggests that the substance dualist may also implicitly accept a Humean account causation in the case of mental-material interaction (Nagel 1979, 193-94).
} 
purely material functioning, we must assume that matter itself includes some mental properties. This argument for panpsychism is known as The Genetic Argument. There are very few theological implications for following these first four steps. Panpsychism, thus defined and argued for, entails no particular view of God. Yet, one particular view of God has dominated theistic versions of panpsychism throughout the twentieth century; Process theism. However, a theologian who has taken the four steps towards panpsychism outlined above should not throw in the towel and adopt a Process view of the world, God, or the God-world relation. To argue this, the remainder of this paper will outline two further steps that a theologian should take to become a theological panpsychist but not a Process theologian.

\section{How not to be a Process theologian}

Since nothing in Steps 1-4 implies any particular view of God, one may attempt to avoid Process theology merely by taking no further steps and remaining atheistic or agnostic on the existence of God at all. ${ }^{5}$ However, for the Christian or theist attracted to panpsychism such silence is not an option. The Christian who is attracted to panpsychism needs to tell some story about how panpsychism fits into their theistic worldview. What difference does a fundamentally conscious creation have for Christian theology? More particularly, what implications might panpsychism have for Christian articulations of environmental ethics, the image of God, the incarnation, the eucharist, the resurrection of the body and other doctrine pertinent to questions of materiality and embodiment? This paper does not attempt to answer all these questions but does briefly consider two

\footnotetext{
${ }^{5}$ Although I have not argued it here, I think this agnosticism or atheism would be unsustainable, because The Genetic Argument implies belief in the existence of a Creator.
} 
important theological issues in light of panpsychism; personal continuity over time and the God-world relation.

Above, I suggested that the three strings on the bow of Process theology are (1) panpsychism, (2) an event ontology, and (3) Process theism. In order to differentiate theological panpsychism from Process theology the remaining sections deny (2) and (3). Step 5 affirms the use of a substance ontology in conjunction with panpsychism, thus facilitating personal continuity over time. Step 6 argues that there is a fittingness between panpsychism and the doctrine of creation ex nihilo. In truth, to take either one of these moves is a step outside of the Process camp, but to be a theological panpsychist (as I am defining the position) one should take both steps.

\section{d) Step 5: Affirm A Substance Ontology}

As with the panpsychism outlined above, Alfred North Whitehead argued that the overconfident disenchantment of matter inherited from René Descartes led to the contradictions of scientific materialism and sought to argue that mentality was at the heart of "the constitution of nature." (Whitehead [1925] 1967, 73) Rather than merely adding mental properties to material substance or positing that mental and material substances may be intrinsically bound together, Whitehead sought to overthrow the whole edifice of substance ontology. Whitehead argued that reality fundamentally consists in "occasions of experience" (Whitehead [1933] 1967) or "actual occasions," (Whitehead [1928] 1978) which are momentary events in time rather than in enduring substances that underlie properties. All of the subjects and objects in the world, which appear to endure through time, are in fact a series of such occasions or a stream of experiences that flicker into actual existence and then, as they immediately 
pass out of actuality, generate part of a new occasion in the series. ${ }^{6}$ Even God is either an actual occasion (Cobb 2007, 81-111) or "an everlasting series of occasions of experience," rather than an eternal subject (Griffin 1983, 136 n.5). ${ }^{7}$ Since there are no enduring fundamental conscious subjects on this account, but only streams of experience, Process philosophers prefer the term panexperientialism to panpsychism. Process thinkers argue that panexperientialism does not face the same core difficulty as panpsychism; namely, the challenge of providing an account of how many fundamental subjects combine to form a complex human subject. Whilst there is no a priori reason to assume that subject combination is impossible, it currently remains a mystery. Panexperientialism claims to avoid this mystery, but at a very steep cost. Process philosophy does not have to explain the combination of subjects because it denies the existence of enduring subjects at any level.

Process thinkers, and other panexperientialists, suppose that experiences can float free of subjects. For panexperientialists, fundamental entities are not brief and basic subjects who have (perhaps) a single experience of existing or being in pain or something and then pass away, they are an anonymous occasion of experience. But how can this be? How can there be the experience of pain without someone who is actually in pain? It is "an obvious conceptual truth," Sidney Shoemaker asserts, "that an

\footnotetext{
${ }^{6}$ This 'inheritance' is the 'physical' pole of the generation account of actual occasions. The 'mental' pole, whereby novelty is introduced into the world is discussed below. ${ }^{7}$ Whether God is an actual occasion, or a series or stream of occasions is one of the substantial divides in Process theology; Whitehead and John Cobb Jr. prefer the former, whereas Charles Hartshorne and David Ray Griffin side with the latter. Whitehead also understood God as the "principle of limitation," which both orders relative values in the world and accounts for the reality of eternal objects, whereby granting all other actual occasions their "initial aim." However, as Cobb narrates, Whitehead later switched to refer to God as an "actual entity" over a fear that the principle of limitation/God may appear overly abstract, rather than existing as a concrete entity. Hartshorne, then argued that as a stream of occasions, the Process God would be more dynamic, capable of sympathy and change.
} 
experiencing is necessarily an experiencing by a subject of experience, and involves that subject as intimately as a branch-bending involves a branch." (Shoemaker 1986, 10). Even if we cannot know very much about the nature of subjects (and fundamental subjects in particular), the existence of subjects as the thing that has experiences cannot be denied (as affirmed in Step 1).

Without enduring subjects, Process metaphysics starts to break down. How can a free-floating experience do anything - such as prehend, feel, respond to God's lure, or act spontaneously - if they are not agential subjects (Abraham 2017, 139-40). ${ }^{8}$ Process metaphysics resolutely denies that actual occasions are enduring subjects (even for the briefest moment) because this would imply a return to substance metaphysics - the rejection of which is the bedrock of Process metaphysics. A self, such as a human self, is a series of these non-subject experiences who have formed a society. As to how this society forms, Whitehead was as much in the dark as panpsychists facing the traditional combination problem of subjects; "the many become one, and by this miracle achieve a triumph of effectiveness" as subjective agents (Whitehead 1951, 690. Italics added). A panpsychist need not follow Process thinkers down the garden path of event ontology. Instead a panpsychist should hold on to a substance based ontology, and with it to the fundamental nature of subjects as the buildingblocks for personal continuity over time. Due to the general instability and flux of quantum entities or other fundamental particles, it is likely that fundamental subjects exist for the briefest of temporal periods. In this sense, fundamental subjects may appear similar to an actual occasion, but

\footnotetext{
${ }^{8}$ This weaker view is notoriously problematic for questions of moral responsibility; if the previous version of 'I' committed the crime, then how can it be just to punish the present and future versions of 'I'? Charles Hartshorne stated this problem in reference to how a person's beliefs can change over time when he admitted that in such "there are really successive believers." (Hartshorne 1970, 181)
} 
the difference remains vital. Only enduring subjects (even brief ones) can form the basis for longer enduring subjects at the level of human existence. Moreover, to be consistent in the denial of brute emergence (Step 4), a panpsychist should not affirm that subjects can emerge from non-subjects, including pure subjectless experiences. This is not to assume that subjects pre-exist or even stand behind experiences in any transcendental sense. For all panpsychists creaturely subjectivity goes along with a living body and cannot be separated from it.

\section{Step 6: Affirm Creation ex Nihilo}

The event ontology and its repercussions for personal continuity in both life and afterlife are not the only differentiating feature of Process theology. In fact, these are secondary in comparison to the idiosyncratic view of God within Process theology. To be a theological panpsychist, but not a Process theologian one must affirm the doctrine of creation ex nihilo. In articulating this step, we will summarise the Process view of God and why this view entails the denial of creation ex nihilo. I argue that panpsychism is not only compatible with the affirmation of creation $e x$ nihilo and the doctrine of God crystallised in this teaching, but that there is a significant fittingness between panpsychism and creation ex nihilo.

The God of Process theism is also a 'actual occasion', a never-ending event or process. God is a part of the system of Process metaphysics and plays an essential and unique role in the ongoing creativity of the world. ${ }^{9}$ The Process God actualizes the potentialities of the world by envisioning

\footnotetext{
${ }^{9}$ When I say that the God of Process theology is 'part of the system' in the way that Christian theologians typically deny, I am thinking of Whitehead's famous statement that "God is not to be treated as an exception to all metaphysical principles, invoked to save their collapse. He is their chief exemplification." (Whitehead [1928] 1978, 521). It is in this sense that Process theologians endorse 'naturalism', since the Process God is not 'supernatural' and cannot interrupt or rewrite the processes of the world - God is part of the process and becoming of the world, prisoner to its logic as much as any creature (Griffin 2001, 129-168).
} 
and ordering eternal objects, which then introduce novelty into the series of occasions (Whitehead 1926, 158-159). God's envisioning of eternal objects is also how God attempts to act in the world. By offering eternal objects as new possibilities to the actual occasions God is said to lure each actual occasion towards the good. Importantly, God cannot determine the response by the actual occasion and so cannot be certain of success (Cobb and Griffin 1976, 118). In this way, the existence of evil is not permitted by God, and it is the finite creature's rejection of God's lure that is ultimately and solely to blame for the suffering in the world. For Process theology, God is 'creator' in the sense that without God's actualizing there would be no concrete actual things in the world and no possibility of change or novelty (Whitehead 1926, 158-59; [1928] 1978, 50; Cobb and Griffin 1976, 66). God is the principle of creativity in the world. But, importantly for Process theology, God does not create out of nothing, or ex nihilo.

The doctrine of creation ex nihilo was formulated in the second century in an attempt to differentiate the Christian view of God, and God's relationship to creation, from both middle-Platonist and so-called gnostic theories of the world's creation. Creation ex nihilo means that God created the world not from pre-existent matter with unrealized potentiality, nor as an emanating from the substance of God's own being, nor with the help of any intermediary forces. In Process theology, God's ongoing creativity seems to rely upon events as a kind of pre-existent potentiality and as intermediary 'agents' which co-determine the shape and value of the world.

Creation ex nihilo is not a statement about what God creates; the ontology of the world is not in question here. Instead, this teaching concerns who God is and how God relates to creation; it is thus a "distributed doctrine," 
which ripples out to affect all aspects of the divine economy (Webster 2013, 156). As such, the denial or affirmation of this doctrine results in radically different accounts of the Christian faith.

What the doctrine of creation ex nihilo means is that God has unilateral, unlimited, and universal power over creation; God does not merely actualize potentialities but creates the very potentialities themselves. No creature creates in this way and so this doctrine points to the transcendence of God, where even our language falls short and can only be taken as analogous to the reality of God. A God who creates out of nothing is supernatural; immeasurably different from all natural or created things. For God to create out of nothing means that nothingness does not threaten God the way it threatens creatures, and no-thing can ultimately resist or frustrate the plans of God. God is not part of the system of reality but creates reality itself. Contrary to recent criticisms, creation ex nihilo neither removes God from being in an interactive relationship with creation, nor places God in opposition to creation (Keller 2003; Oord 2015). The rejection of this doctrine in Process theology has helped nonProcess theologians rediscover the essential importance of this doctrine for Christian thought and practice. Whilst there is a radical and unparalleled divide between Uncreated and created, the claim that God did not need intermediaries or pre-existent potential to create the world shows that God is intimately close to all things - at the very core of their existence and so closer than we are to ourselves - and ensures God's power to save the world from the forces of darkness.

Whilst Process theism employs the resources of panexperientialism to articulate God's nature, power, creativity, and activity, the relationship between Process theism and panpsychism is asymmetrical; a Process theologian must, by definition, employ panexperientialism, but a 
theological panpsychist does not need to employ Process theism. Process theology entails panpsychism; panpsychism does not entail Process theology. Moreover, there is a fittingness between a panpsychist view of the relationship between mind and matter and the Christian doctrine of creation ex nihilo.

As stated above, the doctrine of creation ex nihilo does not concern what kind of creation God has, in fact, created. It is, therefore, compatible with a materialist, dualist, or panpsychist universe. In reaction to the gnostic shunning of material existence, the Christian teaching of creation ex nihilo is a way to affirm the goodness of embodiment. However, there has been "too much emphasis on the creation of matter" in the rediscovery of this doctrine, which concerns all reality (Soskice 2018, 49, 50-51). In Athanasius' De Incarnatione, for example, it is clear that the creation ex nihilo not only regards God's will to create, love to preserve, and power to save the body, but also the soul. Indeed, the argument that motivated the development of creation ex nihilo, God's power to resurrect humanity both body and soul, fits well with the aetiological unity between the body and soul found in panpsychism.

The progenitor of this doctrine, Theophilus of Antioch, articulates a close relationship between Christian teaching on creation and resurrection when he defends the Christian hope for resurrection on the basis that "God created man out of nothing, in that he formed him from a tiny drop of seed which did not exist before." (Theophilus of Antioch 1857-66, 6.1029B; cf. McFarland 2014, 1, 6-8) Such reference to a 'seed' suggests a stronger link than has yet been recognized between Theophilus and the Gnostic defender of creation ex nihilo, Basilides, who argued that the world was created from absolutely nothing in the form of a cosmic seed of not-yet 
being, i.e. potentiality (Osborn 2001, 68-69; contra May 2004, 68-70, 84, 163).

Gregory of Nyssa, over a century later, also drew heavily upon the notion of "the seed of all things" such that souls are within matter and both are created "at the beginning" and allowed to develop "little by little" by progressing "from the least perfect to the most perfect" (In hexaem. I, 77 D; von Balthasar 1995, 58). As such, Gregory could affirm that "creation is self-contained, without experiencing the need for a new intervention and without diminution, as it continues in its arrangements."(Nyssa [1893] 1995 I.610.BC). ${ }^{10}$ There is a panpsychist version of the doctrine of creation ex nihilo here, whereby God created all things from nothing by creating, sustaining, and guiding, a single seed from which the material and mental complexities of this world developed and evolved together. Souls, on this view, are not later additions of anima ex nihilo inserted into creation to demarcate humankind out as unique from other creatures but have the same origin as matter from the beginning.

In contrast to Process theology, a panpsychist articulation of creation ex nihilo affirms that consciousness is, to paraphrase Chalmers' statement quoted above, 'just another created phenomenon.' There is nothing particularly transcendent, divine, or immortal about experience. Instead, consciousness as a fundamental aspect of the material creation evolves through the development of spacetime and exists only because God wills it to do so. According to the doctrine of creation ex nihilo, the only theologically ultimate contrast is found between the Uncreated and the created. The distinction between mentality and materiality pales in comparison. Theologically speaking, it makes more sense to consider both

\footnotetext{
${ }^{10}$ Hans Urs von Balthasar argues that Gregory depicts creation in this way "in order to prove the indissoluble unity of the spirit and the body and their common history" (von Balthasar 1995, 58, 60).
} 
these aspects of creation as part of a single reality, perhaps evolving from a single seed.

Conclusion: Voila! Theological Panpsychism

This article has shown how to be a theological panpsychist, but not a Process theologian in six steps. The Genetic Argument (Steps 1-4) is not the only way to approach or argue for panpsychism, but it is currently the most popular and largely responsible for the recent interest in analytic philosophy. While panpsychism is counterintuitive to the current Western assumption and mindset, its arguments are sound and promising. Its ultimate success depends upon the combination problem; the ability to provide a satisfactory account of mental chemistry and show how fundamental subjects can combine to form a complex mind. Interestingly, panpsychism frustrates the traditional categories of dualism, monism, materialism and idealism, since it can be characterised in terms of each of these mutually incompatible categories. I take this as a good sign.

Historically panpsychism has been combined with pantheism, panentheism, Process theism and classical theism. The relationship between panpsychism and theism does not arise from within panpsychism itself, but depends upon further commitments that a particular theologian holds. There are some other implications from panpsychism that a theologian may be particularly interested in, such as the origin of the soul (Farris and Leidenhag, forthcoming 2021), personal continuity after death, and formulations of human uniqueness. However, when it comes to the nature of God or the God-world relationship, panpsychism determines nothing. It is in this sense a theologically flexible position. The most important difference between theological panpsychism and Process theology comes in Step 6 of this paper. To affirm the doctrine of creation ex nihilo is the short-handed way of rejecting the Process theologians view 
of God, the God-world relation, divine action, and answer to the problem of evil. Theological panpsychism articulates an account of the soul, it's origin and place in the cosmos that is theologically the same as the material body; these two properties (or substances) come together, are created from the beginning, and both have been ordered and have evolved to form human beings like you and, happily, "I".

\section{Bibliography}

Abraham, William J. 2017. Divine Agency and Divine Action: Exploring and Evaluating the Debate, vol. 1. Oxford: Oxford University Press.

Balthasar, Hans Urs von. 1995. Presence and Thought: An Essay on the Religious Philosophy of Gregory of Nyssa. Translated by Mark Sebanc. San Francisco, CA: Ignatius Press.

Chalmers, David. 1996. The Conscious Mind: In Search of a Fundamental Theory. Oxford: Oxford University Press.

—. 1997. "Facing Up to the Hard Problem of Consciousness." In Explaining Consciousness: The Hard Problem, edited by Jonathan Shear, 9-33. Cambridge, MA: MIT Press.

- 2015. "Panpsychism and Panprotopsychism," in Consciousness in the Physical World: Perspectives on Russellian Monism, edited by Torin Alter and Yujin Nagasawa, 246-76. Oxford: Oxford University Press. Clayton, Philip. 2004. Mind and Emergence: From Quantum to Consciousness. Oxford: Oxford University Press.

Cobb, John B. Jr, 2007. A Christian Natural Theology: Based on the Thought of Alfred North Whitehead. Second edition. Louisville, KN: Westminster John Knox Press. 
Cobb, John B. Jr, and Griffin, David Ray. 1976. Process Theology: An Introductory Exposition. Louisville $\mathrm{KN}$ and London: Westminster John Knox Press.

Farris, Joshua and Leidenhag, Joanna. forthcoming, 2021. Humans, Souls, and Origins: A Conversation. New York/London: Routledge.

Feigl, Herbert. 1958. "The 'Mental' and the 'Physical'," Minnesota Studies in the Philosophy of Science, vol. II, edited by H. Feigl, M. Scriven, and G. Maxwell (Minneapolis: University of Minnesota Press. Graves, Mark. 2008. Mind, Brain and the Elusive Soul: Human Systems of Cognitive Science and Religion. London and New York: Routledge.

Gregory of Nyssa. 1857-66. Patrologiae Cursus Completus, Series Graeca. Edited by J.P. Migne. Paris: Migne.

_. [1983] 1995. De hominis opificio. English translation: On the Making of Man Gregory of Nyssa: Dogmatic Treatises, translated by William Moore and H.A. Wilson. In Nicene and Post-Nicene Fathers, series 2, vol. 5, 386-427, edited by Philip Schaff and Henry Wace. Reprinted. Peabody, MA: Hendrickson.

Griffin, David Ray. 1983. "Relativism, Divine Causation, and Biblical Theology," in God's Activity in the World: The Contemporary Problem, edited by Owen C. Thomas, 117-36. Chico, CA: Scholar's Press.

-2001. Reenchantment without Supernaturalism: A Process Philosophy of Religion. Ithaca, NY: Cornell University Press.

Hartshorne, Charles. 1970. Creative Synthesis and Philosophic Method. SCM Press. 
Jackson, Frank. 1983. "Materialism and Qualia: The Explanatory Gap," Pacifica Philosophical Quarterly 64: 354-61.

James, William. [1890] 1950. The Principles of Psychology. Dover.

Keller, Catherine. 2003. Face of the Deep: A Theology of Becoming. New York: Routledge.

Kirk, Robert, "Zombies", The Stanford Encyclopedia of

Philosophy (Spring 2019 Edition), Edward N. Zalta (ed.), URL = <https://plato.stanford.edu/archives/spr2019/entries/zombies/>.

Leibniz, Gottfried Wilhelm von. 1899. The Monadology and other philosophical writings. Translated by Robert Latta. Oxford: Clarendon Press.

May, Gerhard. 1994. Creation ex Nihilo: The Doctrine of 'Creation out of Nothing' in Early Christian Thought. Translated by A.S. Worrall. Edinburgh: T\&T Clark.

McFarland, Ian A. 2014. From Nothing: A Theology of Creation. Louisville: Westminster John Knox Press.

Thomas Nagel. 1979. Mortal Questions. Cambridge: Cambridge University Press.

- Mind and Cosmos: Why the Materialist Neo-Darwinian Conception of Nature is Almost Certainly False. Oxford: Oxford University Press, 2012.

Oord, Thomas Jay. 2015. Theologies of creation: creation ex nihilo and its new rivals. London/New York: Routledge. 
Osborn, Eric. 2001. Irenaeus of Lyon. Cambridge: Cambridge University Press.

Shoemaker, Sidney. [1986] 1996. The First-Person Perspective and Other Essays. Cambridge: Cambridge University Press.

Skrbina, David. 2005. Panpsychism in the West. Cambridge, MA: MIT Press.

Soskice, Janet. 2018. "Why Creatio ex nihilo for Theology Today?," in Creation ex nihilo: Origins, Development, Contemporary Challenges, edited by Gary A. Anderson and Markus Bockmuehl, 36-54. Notre Dame, IN: Notre Dame University Press.

Strawson, Galen. 2006a. "Realistic Monism: Why Physicalism Entails Panpsychism,” Journal of Consciousness Studies 13: 3-31.

_. 2006b. "Realistic Monism: Why Physicalism Entails Panpsychism." In Consciousness and Its Place in Nature: Does Physicalism Entail Panpsychism? edited by Anthony Freeman, 3-32. Imprint Academic.

- Real Materialism and Other Essays. Oxford: Oxford University Press, 2008.

- 2015. "Real Materialism (with new postscript)," in Consciousness in the Physical World: Perspectives on Russellian Monism, edited by Torin Alter and Yujin Nagasawa, 161-208. Oxford: Oxford University Press.

Theophilus of Antioch. 1857-66. Patrologiae Cursus Completus, Series Graeca, edited by J.P. Migne (Paris: Migne, 1857-66). 
Webster, John. 2013. “'Love is also a lover of life': Creatio ex nihilo and creaturely goodness," Modern Theology 29.2: 156-171.

Whitehead, Alfred North. [1925] 1967. Science and the Modern World. New York: Free Press.

1926. Religion in the Making: Lowell Lectures, 1926. Cambridge: Cambridge University Press.

_. [1928] 1967. Process and Reality, edited by David Ray Griffin and Donald W. Sherburne, cor. Ed. New York: The Free Press.

—. [1933] 1967. Adventures of Ideas. New York: Free Press.

—. 1951. "Immortality," in The Philosophy of Alfred North

Whitehead, edited by Paul Arthur Schilpp, 682-700. Second edition. New York, Tudor. 